Doi: HTTPS://DOI.ORG/10.23910/IJBSM/2017.8.3.1800c

\title{
Residual and Cumulative effect of Zinc on Yield, Quality of Soybean (Glycine max L.) and Various pools of Zinc in a Vertisol of Madhya Pradesh, cv. JS 97-52
}

\author{
Namrata Raghuwanshi ${ }^{1}$, B. L. Sharma ${ }^{1}$, Indu Uikey ${ }^{1}$ and Sunil Prajapati ${ }^{*}$ \\ ${ }^{1}$ Dept. of Soil Science and Agricultural chemistry, ${ }^{2}$ Dept. of Horticulture, Jawaharlal Nehru Krishi Vishwa Vidyalaya, Jabalpur, \\ Madhya Pradesh (482 004), India
}

\section{Corresponding Author}

Sunil Prajapati

e-mail: prajapatisunil4960@gmail.com

\author{
Article History \\ Manuscript No. AR1800c \\ Received in $27^{\text {th }}$ February, 2017 \\ Received in revised form $20^{\text {th }}$ May, 2017 \\ Accepted in final form $5^{\text {th }}$ June, 2017
}

\begin{abstract}
The present field experiment was conducted during Kharif, 2014 at Department of Soil Science and Agricultural Chemistry, Jawaharlal Nehru Krishi Vishwa Vidhyalaya, Jabalpur (M.P.), its resulted that the each and alternate year Zn application significantly increased the plant height, pods plant ${ }^{-1}$, seeds pod ${ }^{-1}$, test weight, grain and straw yield, oil and protein content, Zn uptake by seed and straw, all Zn fractions and organic carbon content in soil after harvest of soybean over single year $\mathrm{Zn}$ application but each and alternate year $\mathrm{Zn}$ application were statistically at par. The application of $5 \mathrm{~kg} \mathrm{Zn} \mathrm{ha}^{-1}$ significantly increased the pods plant ${ }^{-1}$, seeds pod ${ }^{-1}$, test weight, grain and straw yield, oil and protein content, $\mathrm{Zn}$ uptake by seed, water soluble and occluded fraction and organic carbon in soil over control the highest plant height, nodules per plant, $\mathrm{Zn}$ content at different growth stages, total $\mathrm{Zn}$ uptake and available $\mathrm{Zn}$ content in soil were found at $10 \mathrm{~kg} \mathrm{Zn}$

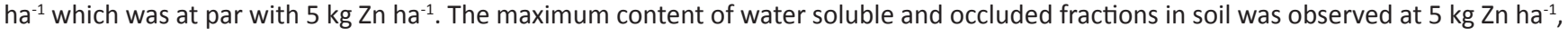
while exchangeable, complexed organically bound, residual and total $\mathrm{Zn}$ fraction was found maximum at $10 \mathrm{~kg} \mathrm{Zn} \mathrm{ha-1.The} \mathrm{water} \mathrm{soluble,}$ exchangeable, complexes, organically bound $\mathrm{Zn}$ fraction in soil has positively significant relationship with grain yield of soybean.
\end{abstract}

Keywords: Soybean, vertisol, zinc, residual, cumulative, Zn fraction, uptake

\section{Introduction}

Soybean \{Glycine $\max ($ L.) Merill\} belongs to family Leguminosae is an important global crop and known as Golden Bean. Soybean is a legume crop, but is widely used as oilseed. It has good potential as an exceptionally nutritive and very rich protein to human diets, because it contain more than $40 \%$ protein of superior quality and all the essential amino acids particularly glycine, tryptophan and lysine similar to cow's milk. Soybean also contain about $20 \%$ oil with an important fatty acid, lecithin and vitamin A and D. All India estimated production for kharif, 2014 is $10.44 \mathrm{mt}$ as compared to $9.48 \mathrm{mt}$ during kharif, 2013. In Madhya Pradesh, the area under Soybean cultivation during kharif, 2014 is 5.55 mha as compared to 6.26 mha during kharif, 2013 showing a decrease of $11.40 \%$. The production during kharif, 2014 was $6.03 \mathrm{mt}$ as compared to $4.32 \mathrm{mt}$ during kharif, 2013 showing an increase of $39.26 \%$ (SOPA, 2014).

The productivity of soybean in Madhya Pradesh is decreasing which might be due to wide spread deficiency of $\mathrm{Zn}$. Khamparia et al. (2010) reported $71 \% \mathrm{Zn}$ deficiency in soil of Madhya Pradesh. Zinc is a metal component of a series of enzymes and chlorophyll formation. The main function of zinc in plant is largely as activator of enzymes viz., carbonic anhydrase, alcohol dehydrogenase, glutamic dehydrogenase etc. Zinc status of plants also plays an important role in plant reproduction. Its deficiency inhibits at different stages of plant reproductive development such as initiation of flowering, floral development, male and female gametogenesis, fertilization and seed development. The Physiological effects of $\mathrm{Zn}$ deficiency in pollen function, fertilization and reproductive development of plants was reported by Pandey et al. (2006).

Zinc occurs in soil in a number of discrete chemical pools differing in their solubility viz., primary and secondary minerals; insoluble inorganic and organic precipitates; soluble organic complexes; exchangeable and adsorbed forms; and soil solution. These forms are in a state of dynamic equilibrium. These pools differ in strength and therefore in their susceptibility to plant uptake, leaching and extractability. The amount and rate of transformation of these forms determine the size of the labile $\mathrm{Zn}$ pools. Adequate supply of soil $\mathrm{Zn}$ to plants depends upon the relative abundance of these different pools and their equilibria which is greatly influenced by crop growth stage and environmental conditions. Plants absorb $\mathrm{Zn}$ from soil solution which is replenished by various 
$Z n$ fractions. The availability of $Z n$ to plants has been observed to vary with different $\mathrm{Zn}$ fractions. The form in which $\mathrm{Zn}$ is present in soil plays a crucial role in determining its availability to plants. The availability of soil $\mathrm{Zn}$ to plants is governed by a dynamic equilibrium among the different fractions of soil $\mathrm{Zn}$ whereas relative availability of $\mathrm{Zn}$ in a soil is mainly governed by chemical changes in soil solution, particularly the $\mathrm{pH}$. About five per cent of total Zn present in soil is available to plants at any given time. Murthy (1982) reported that Zn present in water soluble, exchangeable and complexed form is readily available to the plants, whereas $\mathrm{Zn}$ associated with primary and secondary minerals is relatively unavailable to them. Application of $\mathrm{Zn}$ has been reported significant positive effects, in most cases, on growth measurements and chemical composition of soybean (Gadallah, 2008). In the past years Zinc has assumed greater importance in crop production and its deficiency in the field crops has been recognized on an extensive scale in Madhya Pradesh. In light of above facts field an experiment was framed to study the Residual and cumulative effect of zinc on yield, quality of soybean and different pools of zinc in a Vertisol.

\section{Materials and Methods}

\subsection{Study site}

The present field experiment was conducted during Kharif 2014-15 at Experimental Farm, Department of Soil Science and Agricultural Chemistry, Jawaharlal Nehru Krishi Vishwa Vidhyalaya, Jabalpur (M.P.), the design of experiment conducted in a Split Plot Design with three replications to estimate the effect of $\mathrm{Zn}$ levels and their periodicity on yield and quality of Soybean crop.

\subsection{Method of data collection}

The physico-chemical properties of the soil of the experimental site as sand $(25.4 \%)$, silt $(17.8 \%)$, clay $(56.9 \%)$, soil texture (clay), soil pH (7.1), EC (0.2 dSm ${ }^{-1}$ ) and organic carbon (6.8 g $\left.\mathrm{kg}^{-1}\right)$. The basal dose of $20 \mathrm{~N}-80 \mathrm{P}_{2} \mathrm{O}_{5}$ and $20 \mathrm{k}_{2} \mathrm{O} \mathrm{kg} \mathrm{ha-1}$ was applied at the time of sowing. The Zn levels @ 0, 2.5, 5.0, 7.5, and $10 \mathrm{~kg} \mathrm{Zn} \mathrm{ha-1}^{-1}$ were applied at each, alternate and single year in soybean crop. The effect of increasing $\mathrm{Zn}$ levels on growth parameter (plant height), yield attributes (number of pods per plant, number of seeds per pod, test weight, seed and stover yield), nodulation (three plants other than tagged one were randomly uprooted with full precaution of avoiding damage to roots at 45 days after sowing and mean numbers of nodules were observed) uptake and quality traits i.e., plant zink (Jackson, 1965), protein content (A.O.A.C.,1965), available $Z n$ and $Z n$ fractions determined by atomic absorption spectrophotometer after harvest of soybean were studied.

\section{Results and Discussion}

\subsection{Growth parameters}

The results of the present studies on effect of $\mathrm{Zn}$ application on growth characters, yield component and yield of soybean crops are presented in (Table 1 ). The plant height increased with the increasing levels of $\mathrm{Zn}$ at 30, 45 and 90 DAS over control. The application of $10.0 \mathrm{~kg} \mathrm{Zn} \mathrm{ha}^{-1}$ significantly increased the plant height by (17.0), (20.7) and (25.0) \% at 30, 45 and 90 DAS respectively over control while higher

\begin{tabular}{|c|c|c|c|c|c|c|c|c|c|c|c|c|}
\hline \multirow[t]{2}{*}{$\begin{array}{l}\text { Treatment } \\
\left(\text { kg Zn ha-1) }^{-1}\right.\end{array}$} & \multicolumn{3}{|c|}{ Plant height $(\mathrm{cm})$} & \multirow[t]{2}{*}{ NN } & \multirow[t]{2}{*}{ DWN } & \multirow[t]{2}{*}{ NPP } & \multirow{2}{*}{$\begin{array}{l}\text { No. of } \\
\text { grain } \\
\text { pod }^{-1}\end{array}$} & \multirow[t]{2}{*}{$\begin{array}{l}\text { 1000-grain } \\
\text { weight }(\mathrm{g})\end{array}$} & \multicolumn{2}{|c|}{$\begin{array}{l}\text { Soybean yield } \\
\left(\mathrm{ha}^{-1}\right)\end{array}$} & \multirow[t]{2}{*}{$\begin{array}{c}\text { Oil } \\
\text { content }\end{array}$} & \multirow[t]{2}{*}{$\begin{array}{l}\text { Protein } \\
\text { content }\end{array}$} \\
\hline & $\begin{array}{c}30 \\
\text { DAS }\end{array}$ & $\begin{array}{c}45 \\
\text { DAS }\end{array}$ & $\begin{array}{l}90 \\
\text { DAS }\end{array}$ & & & & & & grain & straw & & \\
\hline 0.0 & 24.70 & 30.08 & 35.24 & 22.12 & 0.30 & 57.78 & 2.78 & 69.49 & 1.50 & 2.33 & 18.15 & 36.58 \\
\hline 2.5 & 27.15 & 33.40 & 39.72 & 24.48 & 0.36 & 67.67 & 3.10 & 77.98 & 1.74 & 3.15 & 18.93 & 37.44 \\
\hline 5.0 & 28.32 & 35.41 & 43.31 & 26.03 & 0.39 & 80.78 & 3.37 & 83.85 & 2.06 & 3.78 & 20.27 & 38.85 \\
\hline 7.5 & 28.62 & 36.15 & 44.04 & 26.83 & 0.41 & 78.56 & 3.32 & 82.20 & 2.03 & 3.77 & 19.68 & 38.43 \\
\hline 10.0 & 28.90 & 36.32 & 44.08 & 26.91 & 0.42 & 74.78 & 3.13 & 81.20 & 1.86 & 3.50 & 19.62 & 37.99 \\
\hline SEm \pm & 0.86 & 0.84 & 0.76 & 0.54 & 0.019 & 2.47 & 0.13 & 2.96 & 0.08 & 0.23 & 0.20 & 0.26 \\
\hline $\mathrm{CD}(p=0.05)$ & 2.47 & 2.40 & 2.19 & 1.54 & 0.05 & 7.06 & 0.36 & 8.47 & 0.23 & 0.66 & 0.57 & 0.76 \\
\hline \multicolumn{13}{|l|}{ Periodicity } \\
\hline Single year & 24.59 & 32.23 & 38.42 & 24.67 & 0.32 & 63.40 & 2.97 & 69.86 & 1.57 & 2.78 & 18.26 & 36.72 \\
\hline Alternate year & 28.3 & 34.78 & 42.14 & 24.83 & 0.37 & 77.93 & 3.26 & 84.88 & 1.98 & 3.60 & 19.48 & 38.06 \\
\hline Each year & 29.71 & 35.81 & 43.28 & 26.32 & 0.44 & 74.40 & 3.13 & 81.38 & 1.96 & 3.54 & 20.26 & 38.79 \\
\hline SEm \pm & 0.89 & 0.64 & 0.92 & 0.44 & 0.01 & 2.48 & 0.05 & 2.45 & 0.09 & 0.15 & 0.26 & 0.32 \\
\hline $\mathrm{CD}(p=0.05)$ & 3.53 & 2.54 & 3.64 & NS & 0.04 & 7.45 & 0.20 & 7.30 & 0.34 & 0.59 & 0.79 & 0.95 \\
\hline
\end{tabular}

NN: No. of nodules; DWN: Dry weight of nodules (g); NPP: No. of pods plant ${ }^{-1}$ 
level of zinc i.e. $2.5,(5.0)$ and (7.5) $\mathrm{kg} \mathrm{Zn} \mathrm{ha}^{-1}$ was statistically at par with that of $10 \mathrm{~kg} \mathrm{Zn} \mathrm{ha}^{-1}$. The periodicity of each year $\mathrm{Zn}$ application increased the plant height by $20.8,11.1$ and $12.6 \%$ over single year. Each year and alternate year $\mathrm{Zn}$ application was found statistically at par. This might be due to more availability and absorption of $\mathrm{Zn}$ from soil solution which caused more seed respiration rate, oxygen carrier, auxin metabolism, synthesis of cytochrome and stabilization of ribosomal fraction, faster cell division and cell elongation and root and shoot development ultimately increased plant height of soybean. However, increasing the rates of photosynthesis and chlorophyll formation due to the $\mathrm{Zn}$, accelerated the meristem activity of plant that led to progressive increase in internode length (Maurya et al., 2010). Kulhare et al. (2014) have also observed significant increase in plant height with the application of $\mathrm{Zn}$. These results are in conformity with those of Chaudhary et al. (2014). The numbers of nodules and dry weight of nodules were increased with increasing levels of $\mathrm{Zn}$ at 45 DAS. The number of nodules plant ${ }^{-1}$ and dry weight of nodule was increased by 22.6 and $40 \%$ at $10 \mathrm{~kg} \mathrm{Zn} \mathrm{ha}^{-1}$ over. However, results also shows that among the treatments 2.5, 5.0, 7.5 and $10.0 \mathrm{~kg} \mathrm{Zn} \mathrm{ha-1}^{-1}$ levels were superior over control and statistically at par. The findings are in agreement with those reported by Awlad et al. (2003) which showed that increasing level of zinc increased the number of nodules.

\subsection{Yield parameters}

Pods plant ${ }^{-1}$ showed that significantly higher values (80.78) were obtained under $5.0 \mathrm{~kg} \mathrm{Zn} \mathrm{ha}^{-1}$ which was $(39.80 \%)$ higher over control (Table 1).The number of seed pod $^{-1}$ ultimately reflects the total economic yield which was highest (3.37 seed pod ${ }^{-1}$ ) under $5.0 \mathrm{~kg} \mathrm{Zn} \mathrm{ha}^{-1}$ which was $21.22 \%$ higher over control. The test weight was highest $(83.85 \mathrm{~g})$ under $5.0 \mathrm{~kg} \mathrm{Zn}$ $\mathrm{ha}^{-1}$ level and significantly superior over control $(69.49 \mathrm{~g})$ which was (20.66\%) higher over control. The periodicity of each year Zn application increased by (22.91), (9.76) and (21.50) \% in number of pods per plant, number of grain per pod and test weight respectively over single year (Fig 3).Each and alternate year $Z n$ application was found statistically at par. Such effects of $\mathrm{Zn}$ application might be due to pivotal role of $\mathrm{Zn}$ in crop growth, involving in photosynthesis processes, respiration and nitrogen metabolism-protein synthesis. Zn plays a key role in biosynthesis of IAA, regulating the auxin concentration in plant and other biochemical and physiological activities and initiation of primordial for reproductive parts and thus ascribed the beneficial effect of to better translocation of desired metabolites to the yield contributing parts of plant. Similar results have been reported by Chaudhary et al. (2014); Nagajyothi et al. (2013).

Zn fertilization @ $5.0 \mathrm{~kg} \mathrm{ha}^{-1}$ enhanced both grain and straw yields significantly by (37.33\%) and (62.23\%), respectively, as compared to control. However the application of increasing level 5 and $7.5 \mathrm{~kg} \mathrm{Zn} \mathrm{ha}^{-1}$ were statistically at par. The periodicity of each year $\mathrm{Zn}$ application increased by $(26.11 \%)$ and $(29.49 \%)$ in grain and straw yield respectively over single year $\mathrm{Zn}$ application. However each and alternate year $\mathrm{Zn}$ application was found statistically at par. This was perhaps due to abundant supply of $\mathrm{Zn}$ nutrition, which increased the protoplasmic constituents, accelerates the process of cell division and elongation, photosynthesis processes, respiration other biochemical and physiological activities (Maurya et al. 2010). Nandanwar et al. (2007) reported that grain and straw yield of soybean increased significantly with Zn $5.0 \mathrm{~kg}$ $\mathrm{Zn}$ application as compared to control. Pable et al. (2010) reported that zinc application increased the grain and straw yield of soybean over control. Similar result also has been also reported by Kanase et al. (2008).

\subsection{Qualitative parameters}

The highest protein content was found at $5.0 \mathrm{~kg} \mathrm{Zn} \mathrm{ha}^{-1}$ which increased by (6.2\%) as compared to control (Table 1 ). However the increasing level of Zn application @ 5.0, 7.5 and $10.0 \mathrm{~kg}$ $\mathrm{Zn} \mathrm{ha}{ }^{-1}$ were statistically at par. The periodicity effect of each year $\mathrm{Zn}$ application was increased by $(5.72 \%)$ over single year but each and alternate year was found statistically at par. The lowest protein content at control might be due to inhibition of protein synthesis and lower activity of Zn containing RNA polymerage. The increased crude protein content in soybean seed with $\mathrm{Zn}$ application might be due to increased Nmetabolism by $\mathrm{Zn}$ application which enhanced accumulation of amino acids and increased the rate of protein synthesis and consequently, protein content in grain. Zinc also helps to improve more nodulation and leghaemoglobin formation which might result higher nitrogen and protein content in soybean. $\mathrm{Zn}$ application in soil enhanced the $\mathrm{Zn}$ concentration in the plant which is associated with RNA and ribosome induction the result of which accelerates protein synthesis (Sonune et al., 2001). Similar finding have been reported by Bairagi et al. (2007); Gaytri et al. (2008); Dhanshree et al. (2010); Kulhare et al. (2014).

The highest oil content was found at $5.0 \mathrm{~kg} \mathrm{Zn} \mathrm{ha}^{-1}$ which was increased by (11.68\%) as compared to control. However the increasing level of Zn application @ 5.0, 7.5 and $10.0 \mathrm{~kg}$ $\mathrm{Zn}$ ha-1 ${ }^{-1}$ were statistically at par. The each year $\mathrm{Zn}$ application increased by $10.95 \%$ over single year but each year and alternate year was found statistically at par. The increase in oil content in soybean seed with Zn application might be due to activation of NADPH dependent dehydrogenase involved in fat synthesis by Zn. Similar finding have been reported by Bairagi et al. (2007); Dhanshree et al. (2010); Kulhare et al. (2014).

\subsection{Zn content at different growth stages}

The application of the increasing levels of $\mathrm{Zn}(2.5,5.0,7.5$ and $10 \mathrm{~kg} \mathrm{ha}^{-1}$ ) significantly increased the $\mathrm{Zn}$ content over control (Table 2). The content of zinc increased by (36.73), (39.20), $(42.24)$ and $(39.88 \%)$ at 45 DAS, 90DAS, seed and straw respectively with the application of $10.0 \mathrm{~kg} \mathrm{Zn} \mathrm{ha}^{-1}$ over control. The periodicity effect of each year application increased the 


\begin{tabular}{|c|c|c|c|c|c|c|c|}
\hline \multirow{2}{*}{$\begin{array}{l}\text { Treatment } \\
\left(\mathrm{kg} \mathrm{Zn} \mathrm{ha}^{-1}\right)\end{array}$} & \multicolumn{3}{|c|}{ Zn content $\left(\mathrm{mg} \mathrm{kg}^{-1}\right)$} & \multirow[t]{2}{*}{ Stover } & \multicolumn{3}{|c|}{ Zinc uptake by soybean $\left(\mathrm{g} \mathrm{ha}^{-1}\right)$} \\
\hline & 45 DAS & 90 DAS & Seed & & Grain & Straw & Total \\
\hline 0.0 & 41.76 & 25.53 & 37.83 & 13.39 & 55.73 & 35.59 & 91.31 \\
\hline 2.5 & 47.93 & 29.87 & 44.39 & 15.03 & 80.91 & 47.84 & 127.54 \\
\hline 5.0 & 51.82 & 31.88 & 49.61 & 16.48 & 100.54 & 63.02 & 163.56 \\
\hline 7.5 & 54.45 & 33.91 & 52.29 & 17.35 & 99.43 & 67.12 & 166.55 \\
\hline 10.0 & 57.10 & 35.54 & 53.81 & 18.73 & 93.54 & 68.12 & 161.66 \\
\hline SEm \pm & 0.91 & 0.53 & 0.51 & 0.29 & 4.51 & 3.99 & 5.23 \\
\hline $\mathrm{CD}(p=0.05)$ & 2.61 & 1.54 & 1.47 & 0.83 & 12.88 & 11.42 & 14.93 \\
\hline \multicolumn{8}{|l|}{ Periodicity } \\
\hline Single year & 45.44 & 27.55 & 43.44 & 14.14 & 65.18 & 39.83 & 105.01 \\
\hline Alternate year & 50.88 & 31.36 & 47.94 & 16.38 & 93.97 & 60.13 & 154.11 \\
\hline Each year & 55.53 & 35.11 & 51.37 & 18.06 & 98.94 & 69.04 & 167.25 \\
\hline SEm \pm & 1.43 & 1.22 & 0.54 & 0.17 & 4.20 & 3.18 & 3.94 \\
\hline $\mathrm{CD}(p=0.05)$ & 4.43 & 3.69 & 1.71 & 0.68 & 16.53 & 9.55 & 11.95 \\
\hline
\end{tabular}

content of $Z n$ by (22.20), (27.44), (18.25) and (27.72\%) at 45 , 90 DAS, seed and stover respectively over single year. The each year $\mathrm{Zn}$ application was found significantly superior over single and alternate year $\mathrm{Zn}$ application. This increase of $\mathrm{Zn}$ content in different growth stages of plant with increasing levels of $Z n$ might be due increasing levels of $Z n$ which increased the $Z n$ availability in soil. Soybean fertilized with $\mathrm{Zn}$, improved the nutritional environment of rhizosphere and consequently in plant system. As the soil of experiment site are marginal in $\mathrm{Zn}$ content $\left(0.70 \mathrm{mg} \mathrm{kg}^{-1}\right)$ and responding to upto $10 \mathrm{~kg} \mathrm{Zn} \mathrm{ha}^{-1}$ in increasing the $\mathrm{Zn}$ content in seed and stover at harvest. The increase of $\mathrm{Zn}$ content in different growth stages of soybean, seed and stover of soybean with increasing levels of $\mathrm{Zn}$ also confirmed by Kobree and Shamsi (2011); Kobree et al. (2011), Chaudhary et al. (2014); Kulhare et al. (2014).

\subsection{Zn uptake}

The application of Zn @ 2.5, 5.0, 7.5 and $10.0 \mathrm{~kg} \mathrm{ha}^{-1}$ significantly increased the $\mathrm{Zn}$ content in grain, straw and total uptake (Table 2). The highest uptake by grain, straw and total uptake were found $100.54 \mathrm{~g} \mathrm{ha}^{-1}$ at $5 \mathrm{~kg} \mathrm{Zn} \mathrm{ha}{ }^{-1}, 68.12 \mathrm{~g}$ $\mathrm{ha}^{-1}$ at $10 \mathrm{~kg} \mathrm{Zn} \mathrm{ha}^{-1}$ and $166.55 \mathrm{~g} \mathrm{ha}^{-1}$ at $7.5 \mathrm{~kg} \mathrm{Zn} \mathrm{ha}^{-1}$ which were increased by $80.40,91.40$ and $82.40 \%$ respectively over control.Zn levels @ 5.0, 7.5 and 10 kg Zn ha ${ }^{-1}$ were found statistically at par among themselves. The periodicity effect of each year application was increased uptake by $51.79,73.33$ and $59.27 \%$ over single year. The each year $\mathrm{Zn}$ application was found significantly superior over single and alternate year $\mathrm{Zn}$ application.

The increases of $\mathrm{Zn}$ uptake with increasing levels of $\mathrm{Zn}$ might be due to increase of yield and $Z n$ content in seed and stover yield as a result of increased $\mathrm{Zn}$ availability in the soil. Which caused higher metabolic and photosynthesis activity in plant resulted in greater uptake of $\mathrm{Zn}$ by crops and this leading to higher dry matter production, which led to higher total $\mathrm{Zn}$ uptake by crops. The higher $\mathrm{Zn}$ uptake due to $\mathrm{Zn}$ application was also reported by Kulhare et al. (2014).

\subsection{Content of $\mathrm{Zn}$ in different pools}

The application of increasing levels of $Z n$ significantly increased the easily exchangeable, complexed, organic bound, occluded, residual and total $\mathrm{Zn}$ content in soil over control and $2.5 \mathrm{~kg} \mathrm{Zn}$ ha ${ }^{-1}$ except water soluble but the higher Zn levels (@ 5.0, 7.5, and $10 \mathrm{~kg} \mathrm{Zn} \mathrm{ha}^{-1}$ ) were found at par among themselves (Table 3). Whereas the maximum residual $\left(65.23 \mathrm{mg} \mathrm{kg}^{-1}\right)$ and total Zn (68.94 mg kg ${ }^{-1}$ ) content was observed with $10 \mathrm{~kg} \mathrm{Zn} \mathrm{ha}^{-1}$ which was increased by 13.56 and $14.78 \%$ over control. The each year $\mathrm{Zn}$ application increased content of $\mathrm{Zn}$ in different pools by (21.42), (16.66), (10.44), (9.5), (14.49), (13.13) and $(13.13 \%)$ in water soluble, easily exchangeable, complexed, organically bound, occluded residual and total $\mathrm{Zn}$ over single year application. Similar finding have been reported by Singh et al. (2013).

\subsection{Correlation between $\mathrm{Zn}$ fraction, yield and uptake by} soybean

It is important to know the relationship between chemical fractions of $\mathrm{Zn}$ with yield and uptake by crop to understand the direct and indirect effects of different fractions of $Z n$ (Table 4). The importance of various forms of $Z n$, either directly or indirectly in influencing the $\mathrm{Zn}$ nutrition of soybean. All the fractions are positively and significantly correlated with grain yield except residual and total $\mathrm{Zn}$ which positively correlated but non-significant. This indicates that plants withdrew $\mathrm{Zn}$ from all the fractions of $\mathrm{Zn}$, directly and indirectly (Ghane, 2011). 


\begin{tabular}{|c|c|c|c|c|c|c|c|c|c|c|}
\hline \multirow{2}{*}{$\begin{array}{l}\text { Treatment } \\
\left(\mathrm{kg} \mathrm{Zn} \mathrm{ha}^{-1}\right)\end{array}$} & \multicolumn{10}{|c|}{ Fraction of $\mathrm{Zn}\left(\mathrm{mg} \mathrm{kg}^{-1}\right)$} \\
\hline & Water soluble & \multicolumn{2}{|c|}{ Easily exchangeable } & \multicolumn{2}{|c|}{ Complexed } & \multicolumn{2}{|c|}{ Organically bound } & Occluded & \multirow{2}{*}{$\frac{d \text { Residual }}{57.44}$} & Total $\mathrm{Zn}$ \\
\hline 0.0 & 0.13 & & & & & & .59 & 1.12 & & 60.06 \\
\hline 2.5 & 0.15 & & & & & & 69 & 1.35 & 58.52 & 61.63 \\
\hline 5.0 & 0.17 & & & & & & .83 & 1.70 & 60.15 & 63.88 \\
\hline 7.5 & 0.16 & & & & & & .85 & 1.69 & 62.66 & 66.40 \\
\hline 10.0 & 0.16 & & & & & & .90 & 1.57 & 65.23 & 68.94 \\
\hline SEm \pm & 0.005 & & & 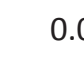 & & & 014 & 0.064 & 0.36 & 0.39 \\
\hline $\mathrm{CD}(p=0.05)$ & 0.015 & & & & & & 040 & 0.183 & 1.03 & 1.14 \\
\hline \multicolumn{11}{|l|}{ Periodicity } \\
\hline Single year & 0.14 & \multicolumn{2}{|c|}{0.24} & \multicolumn{2}{|c|}{0.67} & \multicolumn{2}{|c|}{0.73} & 1.38 & 56.66 & 59.82 \\
\hline Alternate year & 0.16 & \multicolumn{2}{|c|}{0.27} & \multicolumn{2}{|c|}{0.71} & \multicolumn{2}{|c|}{0.79} & 1.50 & 61.64 & 65.05 \\
\hline Each year & 0.17 & \multicolumn{2}{|c|}{0.28} & \multicolumn{2}{|c|}{0.74} & \multicolumn{2}{|c|}{0.80} & 1.58 & 64.10 & 67.68 \\
\hline SEm \pm & 0.005 & \multicolumn{2}{|c|}{0.007} & \multicolumn{2}{|c|}{0.008} & & 012 & 0.032 & 0.42 & 0.22 \\
\hline $\mathrm{CD}(p=0.05)$ & 0.020 & & & & & & 047 & 0.146 & 1.66 & 0.86 \\
\hline $\begin{array}{l}\text { Table 4: Correla } \\
\text { uptake by Soyb }\end{array}$ & $\begin{array}{l}\text { ion between } \mathrm{Zn} \\
\text { an }\end{array}$ & fractio & ield and & & Table & $\begin{array}{l}\text { 5: Effect } \\
\text { uctivity a }\end{array}$ & of differe & $\begin{array}{l}\text { rent levels of } \\
\text { nic carbon an }\end{array}$ & $\begin{array}{l}f \text { zinc on } \mathrm{pH} \text {, } \\
\text { nd zinc cont }\end{array}$ & $\begin{array}{l}\text { electrical } \\
\text { ent in soil }\end{array}$ \\
\hline Parameters Zn & raction & Correlat & lues $(r)$ & & & & & & & \\
\hline & & Yield & Total upt & & $\begin{array}{l}\text { Trea } \\
\text { (kg zr }\end{array}$ & $\begin{array}{l}\text { tment } \\
\left.n \mathrm{ha}^{-1}\right)\end{array}$ & $\mathrm{pH}$ & $E C\left(d \mathrm{dSm}^{-1}\right)$ & $\begin{array}{l}\text { Organic car- } \\
\text { bon }\left(\mathrm{g} \mathrm{kg}^{-1}\right)\end{array}$ & $\begin{array}{l}\text { Soil zinc } \\
\left(\mathrm{mg} \mathrm{kg}^{-1}\right)\end{array}$ \\
\hline Water soluble & & $.959^{*}$ & 0.955 & & 0.0 & & 7.5 & 0.16 & 5.5 & 0.81 \\
\hline Easily exchange & able & $846^{*}$ & $0.961^{*}$ & & 2.5 & & 7.57 & 0.16 & 6.0 & 1.18 \\
\hline $\begin{array}{l}\text { Complex } \\
\text { Organic }\end{array}$ & & $.913^{*}$ & $\begin{array}{l}0.987^{*} \\
0.965^{*}\end{array}$ & & 5.0 & & 7.54 & 0.17 & 6.2 & 1.56 \\
\hline Occluded & & 852 & $\begin{array}{l}0.965 \\
0.983^{*}\end{array}$ & & 7.5 & & 7.51 & 0.17 & 6.4 & 1.81 \\
\hline Residual & & .575 & 0.783 & & 10.0 & & 7.53 & 0.16 & 7.1 & 2.07 \\
\hline Total & & .642 & 0.832 & & SEm \pm & & 0.052 & 0.005 & 0.37 & 0.085 \\
\hline${ }^{*}$ : Correlation is & ignificant at ( & $p=0.0$ & -tailed & & $\mathrm{CD}(p$ & $=0.05)$ & NS & NS & 1.06 & 0.242 \\
\hline Correlation is si & nificant at $(p=c$ & .01) lev & ailed) & & Perio & dicity & & & & \\
\hline & & & & & Singl & le year & 7.55 & 0.16 & 5.3 & 1.10 \\
\hline 3.8. Post-harves & soil properties & & & & Alter & nate & 7.58 & 0.17 & 6.5 & 1.56 \\
\hline The application & of increasing le & els of $z$ & not affec & t soil & year & & & & & \\
\hline pH and EC (Table & 5). While organ & c carbo & ent incre & ased & Each & year & 7.47 & 0.17 & 7.0 & 1.80 \\
\hline significantly d & to ap & $\mathrm{Zn}$ & rol. & & SEm \pm & & 0.034 & 0.006 & 0.44 & 0.050 \\
\hline organic carbon & ontent was to & 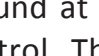 & $n \mathrm{ha}^{-1}$ & ch & $\mathrm{CD}(p$ & $=0.05)$ & NS & NS & NS & 0.197 \\
\hline
\end{tabular}
beneficial effect of $\mathrm{Zn}$ application on production of higher root biomass. The similar finding on $\mathrm{pH}, \mathrm{EC}$ and organic carbon were reported by Chatterjee and Das (1964), Tembhare et al. (1998) and Grewal et al. (1999). Maximum Zn content was found at $10 \mathrm{~kg} \mathrm{Zn} \mathrm{ha}^{-1}$ which was increased by $155 \%$ over control. The significant increase of available $\mathrm{Zn}$ might be due to very high $\mathrm{Zn}$ fixation in clay soil. The similar finding on available $\mathrm{Zn}$ have been reported by Sharma and Lal (1992) and Chitdeshwari and Krishnaswami (1998).

\section{Conclusion}

Alternate year Zn application @ 5.0 kg Zn ha-1 in soybean crop enhanced the yield, quality and uptake by seed and straw of soybean. $\mathrm{Zn}$ content and total uptake was also increased by $\mathrm{Zn}$ application at 10 and $7.5 \mathrm{~kg} \mathrm{Zn} \mathrm{ha-1}^{-1}$ respectively. The water soluble, exchangeable, complexed, organically bound $\mathrm{Zn}$ fraction in soil have positively significant relationship with grain yield and total $\mathrm{Zn}$ uptake by soybean indicating that 
these pools contributing more towards the bio-available $\mathrm{Zn}$ in soil. The residual and total $\mathrm{Zn}$ fractions indicate positive but non-significant relationship with grain yield and total $\mathrm{Zn}$ uptake.

\section{Acknowledgement}

The author is highly acknowledged to Directorate Research Services, Director Instruction and Head Department of Soil Science, JNKVV Jabalpur for assist in conducting the trial successfully, continuous guidance and technical support during field investigation.

\section{References}

A.O.A.C., 1965. Official method of analysis of the association of official agriculture chemists, (10 ${ }^{\text {th }}$ Eds.), 744.

Awlad, H.M., Choudhary, M.A.H., Talukder, N.M., 2003. Effect of Sulphur and Zinc on Nodulation Dry matter yield and Nutrient content of soybean Pakistan Journal of Biological sciences 6(5), 461-466.

Bairagi, B.N., Mahulikar, D.N., Hiwarale, J.S., 2007. Effect of $\mathrm{Zn}$ and $\mathrm{P}$ on yield, oil and protein content of soybean. Journal Soil Crops 17, 292-293.

Chatterjee, R.K., Das, S.C., 1964. Comparative studies on the determination of available zinc in soils varying in mineralogical composition. Journal of Indian Science 12, 297-300.

Chaudhary, P., Jhajharia, A., Kumar, R., 2014. Influence of Sulphur and Zinc Fertilization on Yield, Yield component and Quality Traits of Soybean (Glycine max L.) The Bioscane 9(1), 137-142.

Dhanashree, Pable, P., Deshmukh, P.W., 2010. Effect of sulphur and zinc on yield and quality of soybean. Asian Journal of Soil Science 5(2), 315-317.

Gadallah, M.A.A., 2008. Effects of indole 3- acetic acid and zinc on the growth, osmotic potential and soluble carbon and nitrogen components of soybean plants growing under water deficit. Journal of Arid Environment 44, 451-467.

Gaytri, J., Kakad, Tawar, R.V., Hage, N.D., Ingle, M.B., Fathepurkar, S.C., 2008. Effect of zinc phouphorus on yield and quality parameters of soybean. International Journal of Plant Science 3(2), 355-366.

Ghane, H., 2011. Effect of growing corns on the distribution in soil pools. $2^{\text {nd }}$ International conference on chemical engineering and applications. IPCBEE Vol.23 IACSIT Press, Singapore, 130-133.

Grewal, K.S., Singh, D., Mehta, S.C., 1999. Effect of long term fertilizer application on physic-chemical property of soil. Journal of India Soil Science 47, 538-542.

Jackson, M.L., 1965. Soil chemical analysis. Prentice Hall Inc. Englewood cliffs New Jersey.

Kanase, N., Jadhao, S.M., Konde, N.M., Patil, J.D., 2008. Response of soybean to application of Zn. Agriculture Science Digest 28, 63-64.
Khamparia, R.S., Singh, M.V., Sharma, B.L., Kulhare, P.S., Sharma, G.D., 2010. Four decades of research on micro and secondary nutrients and pollutant elements in soil of M.P. Research publication No. 9 AICRP micro and secondary nutrients and pollutant elements in soil and plant. IISS Bhopal 6, 1-113.

Kobraee, S., Normohamadi, G., Heidarisharifabad, H., Delkhush, B., 2011. The important micronutrient fertilizer on soybean nutrient composition. India Journal of Science and Technology 4, 26-29.

Kobraee, S., Shamsi, K., 2011. Determination of Zn Fe and Mn concentration and partitioning during reproductive stages of Soybean grown under field condition. Research on Crops 12, 752-760.

Kulhare, P.S., Chaudhary, M.K., Uike, Y., Sharma, G.D., Thakur, R.K., 2014. Direct and Residual Effect of $\mathrm{Zn}$ alone and Incubated with Cow Dung on Growth Characters, Zn Content, Uptake and Quality of Soybean [Glycine max (L.) Merrill]-Wheat (Triticum aestivum L.) in a Vertisol. Soybean Research 12(2), 16-21.

Maurya, B.M., Dekate, J., Upadhyay, V.B., 2010. Integrated nutrient management in rice wheat cropping system. JNKVV Research Journal 44, 39-43.

Murthy, A.P.S., 1982. Distribution properties and management of Vertisols of India. Advance in Soil Science 8, 151-214.

Nagajyothi, C., Ravichandra, K., Sudhakara, B., 2013. Effect of foliar supplementation of nitrogen and Zinc on soybean (Glaycine max L.) yield, quality and nutrient uptake. Indian Journal of Dryland Agriculture Research \& Development 28(2), 46-48.

Nandanwar, S.B., Nandanwar, V.B., Jadhao, V.O., Mangre, P.N., 2007. Quality of soybean and fertility status of soil as influenced by N P Zn fertilization and PSB with FYM. Crop production 4, 77-78.

Pable, D., Patil, D.B., Deshmukh, P.W., 2010. Effect of sulphur and zinc on yield and quality of soybean. Asian Journal of Soil Science 5, 315-317.

Pandey, N., Pathak, G.C., Sharma C.P., 2006. Zinc is critically required for pollen function and fertilization in Lentil. Journal of Trace Element and Medicinal Biology 20, 89-96.

S.O.P.A., 2014. Revised Soybean crop estimate for 2014 (www. sopa.org.).

Singh, P., Singh, Y., Singh, V., Sharma, P.K. Meena, R., 2013. Zinc requirement of wheat and its influence on zinc fractions in an inceptisol of Agra, Uttar Pradesh. Crop Research 45(1/3), 84-87.

Tembhre, B.R., Dwivedi, A.K., Tiwari, A., 1998. Effect of continuous cropping and fertilizer use on crop yield and fertility of a Haplustert. Proc. National workshop longterm fertility management through integrated nutrient supply system. IISS, Bhopal, 221-228. 